\title{
A Review of Information Technology Transfer Process, Its Topicality, and Related Models
}

\author{
Viktorija Ponomarenko, Leonids Novickis \\ Riga Technical University, Faculty of Computer Science and Information Technology Contactpoint. Address: \\ Setas str.1, Riga, LV-1007, Latvia.
}

\begin{abstract}
The purpose of the research to provide an overview of technology transfer process to potential readers. The topicality of this issue in the world and the state of Latvian research works with the related topic was analyzed and presented in the paper. The author reviewed experiences of colleagues from other universities for identification main concepts used in this field and existing difficulties to perform technology transfer. The anticipated outcome of this review is the identification of information technology transfer model that could be used for transferring research results from Academia to Business Sector.
\end{abstract}

Keywords: Review, Information Technology Transfer, Technology Transfer Model.

\section{INTRODUCTION}

Nowadays the basis of technology is most commonly comprised of two large groups: a group of information technology and a group of information and communication technology which are based on the use of computers with the aim of processing, receiving, storing, reflecting and transferring information. The goal of information technology is to produce the information meant for making decisions by reducing labour-intensive processes of information resource use.

A lot of the success is directly dependent on a technological solution which could solve the problem more quickly by saving time, money and energy. The life cycle of any kind of information technology begins with its development and continues with transferring the results to the end user. The entrepreneurs of Latvia often cannot afford to invest their money and time in developing new solutions and conducting experiments. In the meantime, plenty of the already developed prototypes remain within university premises and are not passed onto the public. This is because scientists and technology developers are working on the quality and the progress of the technology, meanwhile the transfer process is not well-considered. Therefore, it is crucial to comprehend the process of the technology transfer, particularly from the perspective of the university that holds the role of the manufacturer of the technology and the role of the potential originator of the transfer.

The origins of technology transfer date back to the 1950s. Based on the literature analysis, it was concluded that scientists do not strictly distinguish between the concepts of technology transfer and knowledge transfer and this can be discovered through context. In a number of scientific articles and journals the technology and knowledge transfer carry similar meanings in terms of definitions and one definition can be replaced with the other. When summarizing the given definitions [1] - [12] the technology or knowledge transfer can be interpreted as the process of information transfer from the supplier to the recipient. Generally, this process includes at least two participants that would supply the information, knowledge, technology or experience and would anticipate a number of stages.

\section{II.MATERIALS AND METHODS}

Based on the study aim this research proposal investigates the following questions:

Question 1: What are key terms and concepts in technology transfer?

Question 2: Is there a relationship between "technology transfer process" and "knowledge transfer process"?

Question 3: What is the existing state of technology transfer in the world?

Question 4: What is the role of Latvia in the subject of technology transfer?

Question 5: What are the various models used in technology transfer?

Question 6: What are the most important factors that influence the technology transfer process?

Question 7: What is the future direction of technology transfer for further study?

The aim of this study is to give an overview of the field of technology transfer and show the current state of scientific research regarding this topic. For this http://dx.doi.org/10.17770//etr2017vol2.2544 
purpose, a literature review and bibliometric analyse [13] of the scientific articles published between 1960 and 2016 years indexed in Thomson Reuters' Web of Science (WoS) [14] and Elsevier's Scopus [15] was conducted.

\section{RESULTS AND DISCUSSION}

The number of scientific researches related to technology or knowledge transfer is increasing worldwide every year. To reflect this trend, the bibliometric evaluation method was used [13]. The quantitative analysis was based on the data from the Thomson Reuters' Web of Science [14] and Elsevier's Scopus [15] internationally available databases. It should be pointed out that Elsevier's Scopus contains records of more than 21,000 journals, 86,000 e-books and 6,8 million conference materials as well as 27 million patents, but the Web of Science database contains the most important scientific information on more than 12,000 journals in more than 250 disciplines, offering the bibliographic and citation information, summaries and other information regarding the articles.

The information for the data analysis was compiled for the period from 1960 until the end of 2016 where the technology or knowledge transfer definitions are mentioned in several literary sources. The phrases "technology transfer" and "knowledge transfer" were selected for data processing. The results are reflected in Figure 1 which reflects the topicality of the themes in both databases.

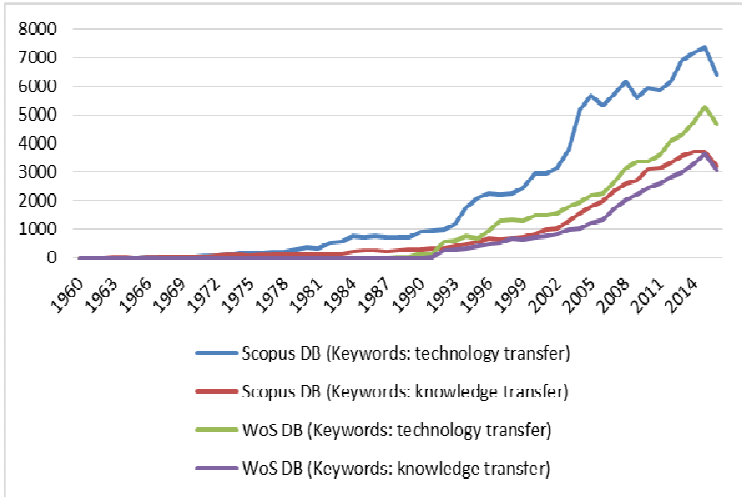

Fig. 1. The technology and knowledge transfer trends within the SCOPUS and Web of Science databases.

As can be seen, starting from 1985 there is a worldwide tendency to pay the most attention to the particular topic. Over the past decade only the SCOPUS and Web of Science databases have annually published about 15,592 scientific papers on average relating to the technology and knowledge transfer and the number of publications is increasing every year.

In terms of information technology, which is based on the use of computers, the information in the field of computer science alone has been collected over the past decade for further data analysis. The phrase "technology transfer" was selected for data processing and the filter "computer science industry" was applied for any searches done. Table 1 summarizes the results.

Table 1.

The number of publications within the SCOPUS and Web of Science databases by keywords "technology transfer" in the computer science sector.

\begin{tabular}{cccc}
\hline Year & WoS & SCOPUS & Total \\
\hline 2006 & 331 & 897 & 1228 \\
2007 & 387 & 1261 & 1648 \\
2008 & 470 & 1548 & 2018 \\
2009 & 498 & 1488 & 1986 \\
2010 & 308 & 1395 & 1703 \\
2011 & 288 & 1261 & 1549 \\
2012 & 385 & 1218 & 1603 \\
2013 & 420 & 1221 & 1641 \\
2014 & 477 & 1239 & 1716 \\
2015 & 608 & 1516 & 2124 \\
2016 & 322 & 1548 & 1870 \\
Total & $\mathbf{4 4 9 4}$ & $\mathbf{1 4 5 9 2}$ & $\mathbf{1 9 0 8 6}$ \\
\hline
\end{tabular}

The bibliometric analysis showed that the theme in relation to the information technology transfer is topical and only the WoS and SCOPUS databases publish around 1,700 articles related to this issue annually. It is important to point out that most researches done in this area have been published by authors from China, the USA and Germany. Unfortunately, the scientists of Latvia still do not pay enough attention to this issue. Only 18 articles by Latvian scientists can be found for the period from 2006 to 2016 within both databases. The total number of publication during this period is reflected in Table 2.

Table 2.

The number of publications by countries for the period from 2006 to 2016 within SCOPUS and WoS databases.

\begin{tabular}{lccc}
\hline Country & $\begin{array}{c}\text { Scopus DB } \\
\text { 2006-2016 }\end{array}$ & $\begin{array}{c}\text { WoS DB } \\
\text { 2006-2016 }\end{array}$ & Total \\
\hline China & 2940 & 969 & 3909 \\
US & 2575 & 795 & 3370 \\
Germany & 965 & 278 & 1243 \\
Japan & 776 & 178 & 954 \\
United Kingdom & 704 & 169 & 873 \\
India & 690 & 261 & 951 \\
Italy & 609 & 170 & 779 \\
South Korea & 555 & 192 & 747 \\
Taiwan & 457 & 170 & 627 \\
$\ldots$ & & $\ldots$ & $\ldots$ \\
Lithuania & 38 & 10 & 48 \\
\hline Estonia & 15 & 9 & 24 \\
Latvia & 11 & 7 & 18 \\
\hline
\end{tabular}


In terms of technology transfer models that are used around the world it must be concluded that there is no single model which can be used and some researchers use different approaches and their experience varies significantly. A lot of new approaches related to technology transfer appear every day and this is influenced by many factors: the aims and the technology transfer policy, the industry needs, the technology quality, the engagement of funding, the government support and other factors. A number of publications were selected in order to compare the models and the scientific experience in the field of technology transfer. The results of the research were summarized in Table 3.

Table 3.

Technology transfer models

\begin{tabular}{|c|c|c|c|c|}
\hline Source & Type of Technology & $\begin{array}{c}\text { Participants involved in the } \\
\text { process }\end{array}$ & $\begin{array}{c}\text { Difficulties to perform } \\
\text { technology transfer }\end{array}$ & Solution \\
\hline$[16]$ & Information & $\begin{array}{l}\text { 1. College } \\
\text { 2.Industrial partner } \\
\text { 3. Third person }\end{array}$ & $\begin{array}{l}\text { Lack of interaction of } \\
\text { participants }\end{array}$ & $\begin{array}{l}\text { 1. Cooperation Technology Transfer in } \\
\text { four programs: } \\
\text { - Mediator } \\
\text { - Direct transfer } \\
\text { - Sharing ideas } \\
\text { - The joint venture } \\
\text { 2. The meetings twice a year }\end{array}$ \\
\hline [17] & $\begin{array}{l}\text { Selected lean manufacturing } \\
\text { tools and techniques }\end{array}$ & $\begin{array}{l}\text { 1. Japanese automotive } \\
\text { industry } \\
\text { 2. UK local companies } \\
\text { 3. Change agents }\end{array}$ & $\begin{array}{l}\text { 1. Time } \\
\text { 2. Management }\end{array}$ & $\begin{array}{l}\text { Quality control and Time-based } \\
\text { competition Based on abstraction level of } \\
\text { the transfer process and whether it is } \\
\text { driven by supply or demand. }\end{array}$ \\
\hline [18] & $\begin{array}{l}\text { Aviation security } \\
\text { technologies }\end{array}$ & $\begin{array}{l}\text { 1. Developer } \\
\text { 2. End-user }\end{array}$ & $\begin{array}{l}\text { Poor understanding of the } \\
\text { private capital, unrealistic } \\
\text { expectations of business } \\
\text { innovation research grants, } \\
\text { lack of understanding of } \\
\text { university best practices. }\end{array}$ & $\begin{array}{l}\text { TECHNOGY TRANSITION- } \\
\text { TRANSFERCOMMERCIALIZATION } \\
\text { MODEL that includes requirements } \\
\text { development, assessment and evaluation, } \\
\text { certification, qualification and approval to } \\
\text { end-user application. }\end{array}$ \\
\hline [19] & Research findings & $\begin{array}{l}\text { 1. Researcher } \\
\text { 2. Practionier }\end{array}$ & $\begin{array}{l}\text { 1. Management } \\
\text { 2. Size } \\
\text { 3. Complexity } \\
\text { 4. Stakeholder involvement } \\
\text { 5. Criticality } \\
\text { 6. Uncertainty }\end{array}$ & Risk assessment \\
\hline$[20]$ & $\begin{array}{l}\text { Tools, products, methods, } \\
\text { techniques, models, } \\
\text { frameworks and others that } \\
\text { enable or support the creation } \\
\text { of } \\
\text { software intensive products } \\
\text { or services }\end{array}$ & $\begin{array}{l}\text { 1. Researchers } \\
\text { 2. Practioniers }\end{array}$ & $\begin{array}{l}\text { Lack of interaction } \\
\text { between center and } \\
\text { company }\end{array}$ & $\begin{array}{l}\text { 1. Open (Ended) Debate } \\
\text { 2.Conclusions in specific post-conference } \\
\text { reports }\end{array}$ \\
\hline$[21]$ & $\begin{array}{l}\text { Research projects in Software } \\
\text { Engineering }\end{array}$ & $\begin{array}{l}\text { 1.Academy } \\
\text { 2.Industry }\end{array}$ & $\begin{array}{l}\text { Reliability and feasibility } \\
\text { of technologies, } \\
\text { their applicability to } \\
\text { industrial settings }\end{array}$ & $\begin{array}{l}\text { Theory and } \\
\text { set of hypotheses extracted from an } \\
\text { exploratory survey with } \\
\text { industrial and academic partners }\end{array}$ \\
\hline$[22]$ & Electric machinery & $\begin{array}{l}\text { 1. Producer } \\
\text { 2. User }\end{array}$ & $\begin{array}{l}\text { Readiness of its human } \\
\text { ware }\end{array}$ & $\begin{array}{l}\text { The measurement model based on } \\
\text { characteristic of a person that have causal } \\
\text { relationship with } \\
\text { work achievement }\end{array}$ \\
\hline$[23]$ & Research results & $\begin{array}{l}\text { 1.Academy } \\
\text { 2.Industry }\end{array}$ & $\begin{array}{l}\text { Low perception of } \\
\text { usefulness }\end{array}$ & $\begin{array}{l}\text { Technology } \\
\text { transfer maturity evaluating model based } \\
\text { on Requirements Traceability }\end{array}$ \\
\hline [24] & Innovation & $\begin{array}{l}\text { 1. Scientific research } \\
\text { institutes } \\
\text { 2. Local governments } \\
\text { Enterprises }\end{array}$ & $\begin{array}{l}\text { Lack of interaction } \\
\text { between actors }\end{array}$ & $\begin{array}{l}\text { Academy-locality cooperation } \\
\text { patterns }\end{array}$ \\
\hline$[25]$ & IT \& ICT technologies & $\begin{array}{l}\text { 1. Owners, developers, } \\
\text { innovators } \\
\text { 2. Users }\end{array}$ & Communication barriers & $\begin{array}{l}\text { STAR (Communication) Model for } \\
\text { technology transfer }\end{array}$ \\
\hline
\end{tabular}


By summarizing multiple sources it can be concluded that a number of technology transfer models include the following common parts:

- the transfer object;

- two or more participants involved in the technology transfer process;

- the interaction between the participants;

- the transfer method which involves a number of steps;

- the environmental factors influencing the technology transfer process.

In addition, several sources indicate that the technology/knowledge transfer is directly related to the concept of innovation. Many research papers [26] - [31] use terms such as "knowledge innovation", "technology innovation", "new knowledge", "new technology" in the context of technology/knowledge transfer. According to the definition from the Merriam-Webster dictionary [32], the "innovation" concept is to be understood as something new to the market and the synonyms to the technology transfer are substantial.

\section{CONCLUSION}

As a result of the research it was concluded that the technology transfer is a topical theme worldwide and the number of scientific researches is only increasing annually. Most of the researches and the technology transfer models have been offered by the scientists from China, the USA and Germany. In Latvia the technology transfer process has not entirely been studied yet and, as a result, the scientists hardly ever communicate with the industry and everyone works separately. Based on the key concepts of the technology transfer, the foreign experience and the best practices, it has been decided to develop a new information technology transfer model and a way of its practical application, taking into account the environmental factors and the conditions within the Latvian market.

\section{V.ACKNOWLEDGMENTS}

This study was partly supported by Latvian National Research Programme "Cyber-physical systems, ontologies and biophotonics for safe\&smart city and society" (SOPHIS) Project No.2 "Ontologybased knowledge engineering technologies suitable for web environment".

\section{REFERENCES}

[1] E. Rogers, M Everett. Diffusion of innovations. Free Press of Glencoe, New York, 1962, 1st.ed. pp. 282-283.

[2] D J..Teece. Technology Transfer by Multinational Firms: The Resource Cost of Transferring Technological Know-How. The Economic Journal, 87(346):242-261, Jan. 1987

[3] F. William, D. V. Gibson. Technology Transfer: A Communication Perspective. Sage Publications: Beverly Hills, London, 1990, pp. 393-404.

[4] P. Shiowattana, Transfer of Japanese Technology and Management to the ASEAN Countries. Tokyo. University of Tokyo Press, 1991, pp. 285-286.
[5] M. S.Spann, M Adams., and W. E. Souder Measures of technology transfer effectiveness: key dimensions and differences in their use by sponsors, developers and adopters. Engineering Management, IEEE Transactions on, vol. 42, no. 1, pp. 19-29, 1995 .

[6] OECD. The knowledge-based economy, organisation for economic co-operation and development. Paris, OECD Publishing, 1996.

[7] G.Lundquist, J. Thompson Technology Quality Management. Technology Transfer Society Proceedings, 1999, Part 1.

[8] OECD. Knowledge Management in the Learning Society. Paris, OECD Publishing, 2000.

[9] Ministry of Education and Science. Guidelines for Development of Science, Technology and Innovations for the years 2014-2020. Riga, 2013, $97 \mathrm{p}$

[10] G. Vekinis Best practice for technological transfer. A best practice manual for successful transfer of technologies, knowhow and knowledge to industry, commerce and society, Greece, 2007, 5 p.

[11] J. Aymen, F. Michaud, M.. Irle, A. Ndiaye. Structuring and representation of scientific knowledge for a transfer through an electronic knowledge-book. In: 2011 IEEE International Conference on Service-Oriented Computing and Applications (SOCA), 12-14 Dec. 2011, pp.1-7

[12] I. Asahi, S. Kunio. Knowledge Transfer in a Large Technology Company:Identification of Key Factor Affecting Broker's Knowledge Approval. In: 2015 Proceedings of PICMET '15: Management of the Technology Age., pp.1-11.

[13] OECD. Glossary of statistical terms. Frascati Manual, Sixth edition. 2002, Annex 7, paras. 20-22, page 203, Oxford Dictionaries, 2013.

[14] Discover Thomson Reuters, Fact Sheet. 2014, Thomson Reuters, Available at: http://thomsonreuters.com/en/productsservices/scholarly-scientific-research/scholarly-search-anddiscovery/web-of-science.html

[15] Elsevier. About SCOUPS. 2017 Elsevier Available at: https://www.elsevier.com/solutions/scopus

[16] Goodman.J. Industry partners-- A technology transfer model for academia. OCEAN 75 Conference Proceedings , 1975, Pages: 850 - 854, DOI: 10.1109/OCEANS.1975.1154144

[17] C. Herron, C. Hicks. The transfer of selected lean manufacturing techniques from Japanese automotive manufacturing into general manufacturing (UK) through change agents. In: Robotics and Computer-Integrated Manufacturing, Volume 24, Issue 4, August 2008, Pages 524 531, doi: http://dx.doi.org/10.1016/j.rcim.2007.07.014

[18] E. Rao, J. Remer, D. Bauer. A model for development, transition and technology transfer leading to commercialization of security technology. In: 2014 International Carnahan Conference on Security Technology (ICCST) Proceedings, IEEE, 2015, doi: 10.1109/CCST.2014.6987007

[19] H..Taylor, E. Artman, J.P. Woelfer. Information technology project risk management: Bridging the gap between research and practice. In: Journal of Information Technology 27(1), JIT Palgrave Macmillan ,2012, pp.17-34, doi: $10.1057 /$ jit.2011.29

[20] C. Henrique, D.T. Gorschek Technology transfer Requirements Engineering research to industrial practice an open (ended) debate. In: 2015 IEEE 23rd International Requirements Engineering Conference (RE) Proccedings, IEEE, 2015, pp. 414-415, doi: 10.1109/RE.2015.7320462

[21] P. Diebold Vetro, A.D.M.. Fernandez. An Exploratory Study on Technology Transfer in Software Engineering. In: 2015 ACM/IEEE International Symposium on Empirical Software Engineering and Measurement (ESEM) Proccedings, IEEE, 2015, pp. 86-95, doi: 10.1109/ESEM.2015.7321189

[22] I. Inrawan.,I. Sunaryo,R.N Syafrian, R. Govindaraju The measurement of humanware readiness in a technology transfer process: Case study in an electrical machinery company. In: 2014 2nd International Conference on Technology, Informatics, Management, Engineering \& Environment Proccedings, IEEE, 2015, pp. 321-325, doi: 10.1109/TIME-E.2014.7011639 
Environment. Technology. Resources, Rezekne, Latvia Proceedings of the $11^{\text {th }}$ International Scientific and Practical Conference. Volume II, 128-132

[23] B. Wang. Requirements Traceability Technologies Selection for Industry. In: 2016 IEEE 24th International Requirements Engineering Conference Proccedings., IEEE, 2016, pp. 450455, doi: 10.1109/RE.2016.72

[24] O.Sun, H. Feng. Innovating the New Model of AcademyLocality Cooperation. In: 2016 International Conference on Industrial Economics System and Industrial Security Engineering (IEIS) Proccedings, IEEE, 2016, doi: 10.1109/IEIS.2016.7551871

[25] A.K Saini, V. KumarKhurana. ICT based communication systems as enabler for technology transfer. In: 2016 3rd International Conference on Computing for Sustainable Global Development (INDIACom) Proccedings, IEEE, 2016, pp. 90-99.

[26] L. Gongli, W. B. Yumei Weijun.. Research on the coupling empirical of knowledge innovation, talent development and technological innovation. In: Control and Decision Conference (2014 CCDC), The 26th Chinese, pp.5320-5324,

[27] W. Zhang Research on Innovation-Generating and Innovation-Transferring. In: 2011 International Conference on Management and Service Science. Pages: 1 - 4, DOI: 10.1109/ICMSS.2011.5997985
[28] D. Vilnis „Inovācijas pasaulē, Eiropā, Latvijā”, Rīga: LZA EI, Latvijas Zinātnu akadēmijas Ekonomikas institūts, 2003

[29] Y. Qun, X. Lingling. The knowledge transfer influence factors of industrial technology innovation coalition based on system dynamics research. In: 2011 International Conference on Business Management and Electronic Information Year: 2011, Volume: 2 Pages: 684 - 688, DOI: 10.1109/ICBMEI.2011.5918005

[30] D. Zimmerman, T. Yohon, L. Stapel. Using Theory to Enhance Technology Transfer and Diffusion of Innovations. 2007 IEEE International Professional Communication Conference, Year: 2007, Pages: 1 - 5, DOI: 10.1109/IPCC.2007.4464099

[31] Q.Sun, H. Feng. Innovating the New Model of AcademyLocality Cooperation. In: Industrial Economics System and Industrial Security Engineering (IEIS), 2016.

[32] Innovation [Def. 1]. (n.d.). Merriam-Webster Online. In Merriam-Webster. Retrieved January 2, 2016, from http://www.merriam-webster.com/dictionary/citation. 